\title{
SPECYFIKA USTROJU HIERARCHICZNEGO KATOLICKICH KOŚCIOLÓW WSCHODNICH
}

Treść: Wstęp. -1 . Kościoły patriarchalne. -1 1.1. Urząd Patriarchy. -1.2 . Struktury synodalne w Kościołach patriarchalnych. - Kościoły arcybiskupie większe. 3 . Kościoły metropolitalne. -4 . Pozostałe Kościoły sui iuris. -5 . Wewnętrzny podział administracyjny katolickich Kościołów wschodnich. -6 . Wybór biskupów wschodnich. - Zakończenie.

\section{Wstęp}

Aby wyjaśnić, cóż tak specyficznego jest w ustroju katolickich Kościołów wschodnich, słusznym wydaje się nawiązać w dwóch słowach do wydarzeń sprzed stuleci. Genezy znakomitej większości katolickich Kościołów wschodnich trzeba bowiem poszukiwać w uniach nawiązywanych z Kościołem rzymskokatolickim przez hierarchów Kościołów prawosławnych. Te unie, najogólniej mówiąc, przewidywały ze strony wschodniej uznanie prymatu Biskupa Rzymu, papiestwo z kolei zobowiązywało się do uznawania odrębnego obrządku, liturgii i prawa wschoduํ. Jednym z elementów, jaki odróżniał wówczas prawosławnych i katolików, była struktura hierarchiczna. Prawosławie ma ustrój autokefaliczny, który polega na samodzielności danego Kościoła prawosławnego w każdym kraju przy jednoczesnym zachowaniu jedności z innymi Kościołami prawosławnymi. Gdy w XVI wieku nawiązywana była unia brzeska, wówczas biskupi prawosławni do-

\footnotetext{
${ }^{1}$ Por. Artykuły należące do zjednoczenia Kościoła ruskiego z Kościołem rzymskim, przez hierarchię metropolii kijowskiej przygotowane i przedłożone. Tekst w języku polskim, w: B.A. GudzIaK, Kryzys i reforma. Metropolia kijowska, patriarchat Konstantynopola i geneza unii brzeskiej, Lublin 2008, s. 360-365.
} 
magali się od papieża administracyjnej autonomii swojej metropolii kijowskiej w ramach Kościoła katolickiego, zachowania niezależności od hierarchii katolickiej obrządku łacińskiego w Rzeczypospolitej, wynikającej z charakteru wschodniego chrześcijaństwa². Ta autonomia organizacyjna, a w konsekwencji specyfika ustroju hierarchicznego, jest obecna w Kościołach wschodnich także i dziś. Została silnie podkreślona na Soborze Watykańskim $\mathrm{II}^{3}$, a także w zasadach rewizji kodeksu wschodniego, przygotowanych przez Papieski Instytut Wschodni, a aprobowanych na pierwszym zgromadzeniu plenarnym Komisji rewizyjnej w dniach 18-23 marca 1974. W dyrektywie 7 poświęconej obrządkom i Kościołom sui iuris, zapisano, że każdy Kościół wschodni musi mieć własną hierarchię zorganizowaną według starożytnych kanonów i stałej tradycji wschodniej ${ }^{4}$. I rzeczywiście, wedle kan. 27 każdy Kościół wschodni to Kościół sui iuris, a każdy z nich posiada własny stopień autonomii. W tym właśnie wyraża się specyfika ustroju katolickich Kościołów wschodnich, iż w zależności od stopnia dojrzałości i samodzielności są one ustanawiane jako: patriarchaty, arcybiskupstwa większe, kościoły metropolitalne oraz pozostałe Kościoły sui iuris. Ten status jest przyznawany przez najwyższą władzę Kościoła, którą w Kościołach wschodnich - tak samo jak w Kościele łacińskim - stanowi Biskup Rzymski oraz Kolegium Biskupów.

Obecnie, według Annuario Pontificio z 2012 roku, istnieją 22 katolickie Kościoły wschodnie, spośród których 6 ma rangę patriarchatu (są to: chaldejski, koptyjski, syryjski, maronicki, melchicki oraz armeński), 4 to arcybiskupstwa większe (tzn.: rumuński, syro-malabarski, syro-malankarski oraz ukraiński), 3 mają status Kościołów metropolitalnych (czyli: etiopski, rusiński, słowacki), pozostałe 9 to tzw. zwykłe

2 Por. M. Melnyk, Łacińskie tradycje w Kościele greckokatolickim. Historia i teraźniejszość, http:/www.grekokatolicy.pl/aktualnosci/acinskie-tradycje-w-Kociele-greckokatolickim..html, (data dostępu: 5 września 2012 r.).

3 Por. Sobór WaTYKańSKi II, Dekret o Kościołach katolickich wschodnich Orientalium Ecclesiarum, n. 7-11.

4 Por. Nuntia 3(1976), s. 7. 
Kościoły sui iuris (albański, białoruski, bułgarski, chorwacki, grecki, Italo-albański, macedoński, rosyjski, węgierski) .

\section{Kościoły patriarchalne}

Najwyższy stopień autonomii posiadają Kościoły patriarchalne, są one najwyższą rangą jednostką administracyjną w katolickich Kościołach wschodnich. Już od starożytności takie Kościoły powstawały w całym chrześcijańskim świecie, zarówno na Wschodzie, jak i na Zachodzie. Jednak na Zachodzie ta forma grupowania Kościołów nie była za bardzo rozpowszechniona, w konsekwencji także i dziś, wedle legislacji łacińskiej (kan. 438 KPK) patriarcha jest tytułem czysto honorowym, bez żadnej władzy rządzenia. Natomiast na Wschodzie struktura patriarchatu stała się zwyczajną formą dla wielu Kościołów lokalnych. Ze względu na jej wielkie znaczenie dla chrześcijańskiego Wschodu, Sobór Watykański II wskazał, że wschodnim Kościołom katolickim należy ją nadawać 6 . Przy czym, zgodnie z kan. 57 § $1 \mathrm{KKKW}$, zarówno erygowanie, jak i zmiana czy zniesienie Kościołów patriarchalnych są zarezerwowane najwyższej władzy Kościoła.

\subsection{Urząd Patriarchy}

Na czele Kościoła patriarchalnego stoi Patriarcha, który w kan. 55 KKKW został określony jako ojciec i głowa Kościoła, któremu przewodzi ${ }^{7}$. Jest on biskupem, który posiada władzę nad wszystkimi biskupami, w tym także metropolitami, i wszystkimi wiernymi Kościoła,

\footnotetext{
5 Por. Annuario Pontificio 2012, s. 1138-1141.

${ }^{6}$ Por. Sobór WatyKańsKi II, Dekret o Kościołach katolickich wschodnich Orientalium Ecclesiarum, n. 7-11.

${ }^{7}$ Co do etymologii terminu patriarcha, istnieją dwie teorie. Wedle pierwszej, poprzez połączenie słów $\pi \alpha \tau \eta \rho$ (ojciec, rodzic) oraz $\alpha \rho \chi \eta ́$ (pierwszy), winien być on rozumiany jako praojciec, przodek. W takim sensie termin patriarcha znajduje się w Starym Testamencie, gdzie patriarchowie Abraham, Izaak i Jakub reprezentują praojców ludu izraelskiego. Druga teoria stwierdza, że termin patriarcha stanowi połączenie słów $\pi \alpha \tau \rho \iota \alpha$ (kraj) i $\alpha \pi \chi \omega \nu$ (pierwszy, głowa) i że winien być tłumaczony poprzez głowa narodu. - Por. G. Grigoriță, Il concetto di Ecclesia sui iuris. Un'indagine storica, giuridica e canonica, Roma 2007, s. 68.
} 
któremu przewodzi. Takie określenie Patriarchy, bardzo zbliżone do modelu łacińskiej organizacji kościelnej, określającej Biskupa Rzymu jako głowę Kolegium Biskupów (kan. $331 \mathrm{KPK}$ ) powoduje, że niektórzy autorzy nazywają go wręcz papa locale lub in miniatura ${ }^{8}$. Władza Patriarchy, choć zwyczajna i własna, jest na tyle osobista, że wyklucza możliwość zastępstwa w takim sensie, że nie może on ustanowić wikariusza dla całego Kościoła patriarchalnego ani też delegować komukolwiek swojej władzy w odniesieniu do wszystkich spraw (kan. 78 \$1 $K K K W$ ). Nie jest to jednak władza nieograniczona czy bezwarunkowa ponieważ samo historyczne pochodzenie uprawnień ponad-episkopalnych czy ponad-metropolitalnych wymaga, aby byty one ograniczone struktura synodalna Kościoła sui iuris, o której będzie mowa poniżej ${ }^{9}$.

Patriarcha wykonuje swoją władzę według norm prawa zatwierdzonych przez najwyższą władzę Kościoła, przy czym zasadniczo może być ona ważnie wykonywana jedynie w granicach terytorium Kościoła patriarchalnego (chyba że co innego wynika z natury rzeczy albo z prawa powszechnego lub partykularnego zatwierdzonego przez Biskupa Rzymskiego). Jest to eklezjologiczne i kanoniczne potwierdzenie terytorialności jego władzy ${ }^{10}$. Warto wyjaśnić w tym miejscu, co należy rozumieć poprzez terytorium Kościoła. Otóż zgodnie z kan. $146 \S 1$ KKKW są trzy elementy, które je określają: po pierwsze jest to element geograficzny, czyli określony region geograficzny; po drugie element obrządkowy, kanon stanowi bowiem, że chodzi o regiony, w których zachowywany jest ryt właściwy dla tego Kościoła; w końcu po trzecie, element władzy, czyli prawo patriarchy do erygowania w tym regionie prowincji, eparchii i egzarchatów ${ }^{11}$.

8 Por. tamże, s. 71.

9 Por. D. Salachas, Istituzioni di diritto Canonico delle Chiese cattoliche Orientali, Bologna 1993, s. 142; G. Mori, D. Salachas, Ordinamenti giuridici delle Chiese cattoliche orientali, Bologna 2000, s. 73.

${ }^{10}$ Por. G. WoJcIechowski, Ustrój hierarchiczny katolickich Kościołów wschodnich. Wybrane zagadnienia, Lublin 2011, s. 29.

${ }^{11}$ Por. L. Lonusso, Il territorio canonico, w: Pontificio Consiglio per i Testi Legislativi, Il Codice delle Chiese Orientali. La storia le legislazioni particolari, le prospettive ecumeniche. Atti del Convegno di studio tenutosi nel XX animadversario della 
Patriarchowie Kościołów wschodnich mają na całym świecie pierwszeństwo przed wszystkimi biskupami jakiegokolwiek stopnia. Natomiast względem siebie, zgodnie z kan. $59 \mathrm{KKKW}$, są równi z racji godności patriarszej, zachowują natomiast precedencję honorową. W ten sposób pierwszeństwo pomiędzy starożytnymi stolicami Kościołów patriarchalnych zostało ustanowione przez prawodawcę następująco: Konstantynopol, Aleksandria, Antiochia i Jerozolima. O kolejności pozostałych decyduje starożytność siedziby patriarchalnej. Natomiast jeśli kilku Patriarchów posiada ten sam tytuł, wówczas pierwszeństwo przysługuje temu, który pierwszy został podniesiony do godności patriarchy.

Olbrzymia autonomia Kościołów patriarchalnych wyraża się po pierwsze w sposobie wyboru Patriarchy. Otóż jest on wybierany przez Synod Biskupów Kościoła patriarchalnego, wedle procedury kanonicznej przewidzianej w kan. 64-77 KKKW, czyli zasadniczo bez ingerencji bezpośredniej najwyższej władzy Kościoła. Gdy stolica patriarchalna wakuje, wówczas administrator tegoż Kościoła ma obowiązek zwołania Synodu Biskupów, który powinien zebrać się w ciągu miesiąca liczonego od dnia zawakowania stolicy patriarchalnej (kan. $65 \S 2 \mathrm{KKKW}$ ). Patriarcha wybierany jest większością $2 / 3$ głosów przy obecności $2 / 3$ tych, którzy mieli obowiązek wzięcia udziału w wyborach (z tym, że prawo partykularne może przewidywać inne procedury po trzech bezskutecznych głosowaniach). Dopiero jeśli wybór nie zostanie dokonany w ciągu 15 dni od rozpoczęcia Synodu, sprawa zostaje przekazana Biskupowi Rzymskiemu. Prawo nie określa jednak celowości owego ad Romanum Pontificem devolvitur, czyli nie wskazuje sposobu działania papieża w takiej sytuacji (czy wówczas Biskup Rzymski sam dokona nominacji Patriarchy, czy może wskaże dodatkowy termin przeprowadzenia wyborów, czy podejmie jeszcze inną decyzję - zależy jedynie od niego). Jeśli natomiast wybór zosta-

promulgazione del Codice dei Canoni delle Chiese Orientali, Città del Vaticano 2011, s. 396; G. Mori, D. Salachas, Ordinamenti giuridici..., dz. cyt., s. 68; G. Grigoriță, Il concetto..., dz. cyt., s. 62 . 
nie dokonany, a elekt jest już biskupem ${ }^{12}$, wówczas wybór powinien być natychmiast oznajmiony elektowi, a jeśli tenże wybór przyjmuje (o czym powinien zdecydować w ciągu 2 dni), dokonuje się jego ogłoszenia i intronizacji. O powyższych, a także o złożonym wyznaniu wiary i przysiędze wierności, Synod Biskupów musi jak najszybciej powiadomić Biskupa Rzymskiego. Co istotne, po swym wyborze Patriarcha nie zwraca się do papieża o zatwierdzenie, lecz prosi go o łączność w Liturgii Eucharystycznej, tzw. znak wspólnoty kościelnej (kan. $76 \mathrm{KKKW})^{13}$. Lesia Kovalenko tłumaczy, że owo communio patriarchy z Biskupem Rzymu jest wzajemnym uznaniem rzeczywistej jedności w wierze, sakramentach i dyscyplinie, jest fundamentem jedności Kościoła powszechnego ${ }^{14}$. Jednak inni autorzy stanowczo sprzeciwiają się takiemu stwierdzeniu. Jeśli bowiem rzeczywiście mówiłoby się tutaj o wzajemnym uznaniu, wówczas kan. 76 KKKW musiałby zobowiązywać także Biskupa Rzymskiego do proszenia o znak wspólnoty kościelnej Patriarchę. Tymczasem w treści odnośnego kanonu nie mówi się o wymianie listów pomiędzy patriarchą i papieżem, nie nakłada się na tego ostatniego obowiązku analogicznego do tego, który dotyczy Patriarchy. Biskup Rzymu nie podlega bowiem żadnej innej władzy, którą musiałby prosić o uznanie ${ }^{15}$. W konsekwencji trzeba powiedzieć,

${ }^{12}$ Jeśli elekt nie posiada jeszcze święceń biskupich, wówczas należy zachować wszelkie przepisy prawa dotyczące wyboru biskupów, o których będzie mowa poniżej.

${ }^{13}$ Do tego czasu nie może zwoływać Synodu Biskupów ani wyświęcać Biskupów, choć urząd swój sprawuje już od chwili intronizacji. - Por. KKKW, kan. 77 $\S 2$. Jest to konsekwencją faktu, że munus regendi e docendi z natury swojej mogą być wykonywane tylko w hierarchicznej wspólnocie (communio) z Głową Kolegium i z jego członkami (Sobór Watykański II, Konstytucja dogmatyczna o Kościele Lumen gentium, n. 21). - Por. J. Chiramel, La struttura gerarchica delle Chiese Orientali, w: K. Bharanikulangara (red.), Il Diritto Canonico Orientale nell'ordinamento ecclesiale, Studi Giuridici XXXIV, Città del Vaticano 1995, s. 138.

${ }^{14}$ Por. L. Kovalenko, Communio ecclesiastica del Patriarca con il Romano pontefice: questione e dubbi, w: Congregazione per le Chiese Orientali, Ius Ecclesiarum Vehiculum Caritatis. Atti del simposio internazionale per il decennale dell'entrata in vigore del Codex Canonum Ecclesiarum Orientalium, Città del Vaticano 2004, s. 790.

${ }^{15}$ Por. G. Grigoriță, Il concetto..., dz. cyt., s. 73-74; D. SAlachas, Le novità del Codex Canonum Ecclesiarum Orientalium a proposito del primato romano, Folia Canonica 1(1998), s. 122. 
że to Patriarcha prosi o znak wspólnoty kościelnej, Biskup Rzymski mógłby natomiast taką wspólnotę nawet zanegować. Zgodnie z treścią n. 24 konstytucji soborowej Lumen gentium, jeśli następca Piotra wzbrania się lub odmawia przyjęcia do wspólnoty (communio) apostolskiej, biskupi nie moga być powolywani na urząd. Stąd też, gdyby elekt nie gwarantował doskonałej jedności w wierze i sakramentach lub zostałby wybrany w sposób niezgodny z prawem kanonicznym, wówczas Biskup Rzymski nie mógłby udzielić mu znaku owej wspólnoty kościelnej. To należy, zgodnie z n. 9 dekretu Orientalium Ecclesiarum, do jego niepozbywalnego prawa interweniowania w poszczególnych wypadkach ${ }^{16}$.

\subsection{Struktury synodalne w Kościołach patriarchalnych}

Specyfiką ustroju w Kościołach wschodnich są także struktury synodalne. Zgodnie z KKKW w patriarchacie występują trzy figury prawne o charakterze synodalnym: synod biskupów, synod stały oraz zgromadzenie patriarsze.

Synod Biskupów Kościoła patriarchalnego, zgodnie z kan. $102 \S 1$ KKKW, stanowią wszyscy i jedynie biskupi wyświęceni dla tegoż Kościoła i gdziekolwiek ustanowieni, czyli zarówno w granicach, jak i poza granicami Kościoła. Jednak głos decydujący tych ostatnich, podobnie jak biskupów tytularnych, może być ograniczony przez prawo partykularne. Synod Biskupów ma przede wszystkim władzę legislacyjną, sądową oraz prawo wyboru Patriarchów i biskupów. W zakresie władzy legislacyjnej, zgodnie z dyspozycją kan. 110 §1 KKKW, do jego kompetencji należy wydawanie ustaw dla całego Kościoła patriarchalnego, a także określanie czasu i sposobu promulgacji ustaw i publicznego ogłoszenia decyzji. Natomiast sama promulgacja należy już do kompetencji Patriarchy. Ustawy wydane przez Synod Biskupów, jeśli są ustawami natury liturgicznej, mają moc wiążącą wszędzie, w stosunku do wszystkich własnych wiernych; z kolei ustawy dyscyplinarne oraz wszystkie inne decyzje Synodu Biskupów mają

\footnotetext{
${ }^{16}$ Por. D. Salachas, Commento al can. 76, w: P.V. Pinto (red.), Commento al Codice dei Canoni delle Chiese Orientali, Città del Vaticano 2001, s. 87.
} 
moc prawną jedynie w granicach terytorium danego Kościoła, chyba że zostały zaaprobowane przez Stolicę Apostolską (kan. $150 \S \S 2-3$ KKKW). To rozróżnienie pomiędzy ustawami liturgicznymi i wszystkimi innymi ustawami oraz decyzjami jest usprawiedliwione faktem, że patrymonium liturgiczne stanowi zasadniczy element wewnętrznej tożsamości całego Kościoła patriarchalnego ${ }^{17}$. O funkcji sądowej Synodu Biskupów należy powiedzieć przede wszystkim, że - z zachowaniem kompetencji Stolicy Apostolskiej - jest on najwyższym trybunałem w granicach terytorium tego Kościoła ${ }^{18}$. Wybiera on ze swojego gremium moderatora generalnego wykonywania sprawiedliwości oraz dwóch biskupów, którzy wraz z nim stanowią trybunał kolegialny dla rozstrzygania spraw spornych tak eparchii, jak i biskupów. Apeluje się w tych sprawach do Synodu Biskupów Kościoła patriarchalnego, bez możliwości dalszej apelacji (kan. 1062 KKKW), choć z zachowaniem prawa każdego wiernego przedłożenia swojej sprawy, w każdym stadium i na każdym stopniu sądzenia, do rozstrzygnięcia Biskupowi Rzymskiemu. Ponadto Synod Biskupów dokonuje wyboru Patriarchów i biskupów wewnątrz granic terytorium Kościoła patriarchalnego oraz kandydatów na urzędy Biskupów eparchialnych, koadiutorów i pomocniczych, mianowanych przez Biskupa Rzymskiego poza granicami terytorium Kościoła patriarchalnego (kan. 110 §3; 149 KKKW).

Prawo powszechne nie określa ścisłych terminów, w których Patriarcha byłby zobowiązany do zwołania Synodu, wskazuje jedynie okoliczności, które takie zwołanie uzasadniają: jeśli zaistniało wiele spraw, które należą do wyłącznej kompetencji Synodu lub dla ich przeprowadzenia wymaga się zgody tegoż Synodu; Patriarcha, za zgodą Synodu Stałego, uzna to za niezbędne; w danej sprawie domaga się tego co najmniej 2/3 członków Synodu, zawsze przy zachowaniu ustanowionych prawem powszechnym uprawnień Patriarchów, biskupów i innych osób; oraz wówczas, gdy wymaga tego prawo partykularne, w stałych terminach, choćby co roku (kan. $106 \mathrm{KKKW})$.

${ }^{17}$ Por. D. Salachas, Commento al can. 110, w: P.V. Pinto (red.), Commento..., dz. cyt., s. 115 .

${ }^{18}$ Por. J. ChIRAmel, La struttura gerarchica..., art. cyt., s. 139. 
Struktura synodalna w Kościele patriarchalnym realizuje się także w codziennej aktywności administracyjnej Patriarchy, w której wspomagany jest przez kurię patriarchalną, a zwłaszcza organ zwany Synodem Stałym. Jest to instytucja, w skład której wchodzi Patriarcha, który mu przewodzi oraz czterech biskupów ustanawianych na pięć lat. Trzech z nich, wśród których przynajmniej dwóch powinno być biskupami eparchialnymi, jest wybieranych przez Synod Biskupów Kościoła patriarchalnego, jeden zaś jest mianowany przez Patriarchę (kan. $115 \mathrm{KKKW}$ ). Synod ten, który powinien być zwoływany przynajmniej dwa razy do roku, posiada również pewną autonomię, jako że może działać także bez Patriarchy (wówczas liczba członków powinna być uzupełniona do pięciu zgodnie z kan. $115 \S 3 \mathrm{KKKW}$, a sesjom przewodniczy najstarszy święceniami biskup). Synod Stały jest organem administracyjnym, który ma służyć Patriarsze pomocą w rozstrzyganiu różnych ważnych spraw ${ }^{19} \mathrm{i}$ ma głos decydujący co do całego szeregu różnych kwestii (przeszło trzydziestu), powierzonych mu przez prawo powszechne ${ }^{20}$.

W końcu zgromadzenie patriarchalne, które jest zebraniem doradczym całego Kościoła pod przewodnictwem Patriarchy, zwoływanym co najmniej co pięć lat, ma świadczyć mu pomoc w sprawach większej wagi, szczególnie w tym, co dotyczy form i środków apostolstwa oraz dyscypliny kościelnej (kan. 140-145 KKKW).

\section{Kościoły arcybiskupie większe}

Drugim, pod względem rangi, rodzajem Kościoła wschodniego jest Kościół arcybiskupi większy. Arcybiskup większy jest głową tego Kościoła sui iuris i jest zdefiniowany jako metropolita stolicy określonej lub uznanej przez najwyższą władzę kościelną, a któremu nie został nadany tytuł patriarszy (kan. $151 \mathrm{KKKW}$ ). Jednocześnie KKKW postanawia $\mathrm{w}$ kan. 152 , że to, co $w$ prawie wspólnym odnosi się do Kościołów patriarchalnych lub Patriarchów, ma zastosowanie także do Kościołów arcybiskupich większych i do Arcybiskupów większych,

\footnotetext{
${ }^{19}$ Por. tamże.

${ }^{20}$ Por. G. Mori, D. Salachas, Ordinamenti giuridici..., dz. cyt., s. 82 .
} 
chyba że co innego wyraźnie zastrzega prawo wspólne albo wynika to z natury rzeczy. Oznacza to, że Kościół arcybiskupi większy ma ten sam system rządzenia co Kościół patriarchalny. Różnica pomiędzy patriarchą a Arcybiskupem większym polega przede wszystkim na porządku precedencji, a nie na władzy ${ }^{21}$. Ponadto, choć Arcybiskup większy jest wybierany tak samo jak Patriarcha (czyli przez Synod Biskupów większością 2/3 głosów przy obecności 2/3 tych, którzy mieli obowiązek wzięcia udziału w wyborach), to jednak, zgodnie z kan. 153 KKKW, po dokonanym wyborze we własnoręcznie podpisanym liście zwraca się do papieża o zatwierdzenie tego wyboru. To zatwierdzenie jest konieczne dla ważności elekcji i następnie dla objęcia urzędu przez elekta ${ }^{22}$. Stąd dopiero po otrzymaniu zatwierdzenia następuje złożenie wyznania wiary i zaprzysiężenie elekta przed Synodem Biskupów danego Kościoła arcybiskupiego większego, a następnie zostaje przeprowadzona intronizacja. Jeżeli elekt nie zostanie zatwierdzony przez papieża, tenże określa czas, w którym należy dokonać nowego wyboru.

Można powiedzieć, że Kościół arcybiskupi większy to ten, który wskutek obiektywnych przyczyn już przekroczył ramy Kościoła metropolitalnego, ale jeszcze nie zdołał osiągnąc znaczenia i stopnia Kościoła patriarchalnego, choć strukturalnie jest mu podobny. Z punktu widzenia posiadanej władzy nie ma żadnej różnicy pomiędzy Patriarchą i Arcybiskupim większym, okazuje się jednak, że dla Kościołów wschodnich kwestia ta jest bardzo istotna. Mam tu na myśli nade wszystko Ukraiński Kościół Katolicki, który od lat stara się i zabiega o nadanie mu rangi patriarchatu. Nie tak dawno, bo zaledwie w czerwcu 2012 r., na stronie internetowej Katolickiej Agencji Informacyjnej został opublikowany bardzo ciekawy wywiad z arcybiskupem większym kijowsko-halickim Światosławem Szewczukiem. Jedno z zadanych wówczas pytań dotyczyło właśnie tego, dlaczego tak usilnie zabiegacie o patriarchat, skoro i tak Ksiadz Arcybiskup ma de facto uprawnienia patriarchy? W odpowiedzi Arcybiskup wskazał po pierwsze na fakt, że w tradycji Kościołów wschodnich nikt tak do

\footnotetext{
${ }^{21}$ Por. G. Grigoriță, Il concetto..., dz. cyt., s. 76.

${ }^{22}$ Por. G. Mori, D. Salachas, Ordinamenti giuridici..., dz. cyt., s. 85.
} 
końca nie rozumie, co znaczy Arcybiskup większy, bo w świadomości wschodniej arcybiskup to ktoś, kto stoi niżej od metropolity. Po drugie, ma to związek z rozwojem Katolickiego Kościoła Ukraińskiego: przez ostatnie dwadzieścia lat doświadczyliśmy takiego rozwoju, jakiego nigdy w historii nie było. Można wręcz mówić o eksplozji. To powoduje niecierpliwość. Chcemy po prostu osiagną́ ten najdoskonalszy poziom naszego eklezjalnego rozwoju już teraz, kiedy do tego dojrzeliśmy. Arcybiskup podkreślił, że już kard. Josyf Slipyj zwracał się do Soboru Watykańskiego II z prośbą o przyznanie jego Kościołowi rangi Patriarchatu. Kard. Lubomir Huzar prosił o to papieża Jana Pawła II, obecny Arcybiskup zabiegał u Benedykta XVI. Odpowiedź jest zawsze taka sama: Bądźcie cierpliwi, módlcie się i ten dzień przyjdzie ${ }^{23}$.

\section{Kościoły metropolitalne}

Ranga niższa od arcybiskupstwa większego to Kościoły metropolitalne. Nie ma wątpliwości, że posiadają one znacznie mniejszy stopień autonomii niż Patriarchaty i Kościoły arcybiskupie większe. Po pierwsze wyraża się to w sposobie nominacji Metropolity: nie jest on bowiem wybierany, ale mianowany przez Biskupa Rzymskiego, któremu Rada Hierarchów przesyła listę przynajmniej trzech najbardziej odpowiednich kandydatów (kan. $168 \mathrm{KKKW}$ ). Po nominacji Metropolita winien poprosić Biskupa Rzymskiego o paliusz, który jest znakiem władzy metropolitalnej i pełnej jedności z Papieżem: jeśli w chwili mianowania jest już biskupem, wówczas winien to uczynić w ciągu trzech miesięcy od momentu intronizacji; w przeciwnym razie, czas ten liczony jest od momentu święceń biskupich udzielonych nowo wybranemu Metropolicie. Przed nałożeniem paliusza nie może zwoływać Rady Hierarchów i święcić biskupów.

Drugim ograniczeniem jest to, że prawo partykularne Kościołów metropolitalnych musi być przed promulgacją aprobowane przez Sto-

${ }^{23}$ Jeszcze nigdy $w$ dziejach nasz Kościół tak nie rozkwitat. Rozmowa Grzegorza Polaka z Arcybiskupem większym kijowsko-halickim Światosławem Szewczukiem, 11 czerwca 2012 r., http://ekai.pl/wydarzenia/temat_dnia/x55555/jeszcze-nigdy-wdziejach-nasz-kosciol-tak-nie-rozkwital/?print=1 (data dostępu: 6 września 2012 r.). 
licę Apostolską. To zostało wyrażone najpierw w n. 8 kan. 159 KKKW, zgodnie z którym do Metropolity należy „ogłaszać akta Biskupa Rzymskiego, chyba że Stolica Apostolska bezpośrednio to uczyniła". W ten sposób istnieje niewątpliwe ograniczenie autonomii Kościoła metropolitalnego, do tego stopnia, że niektórzy kanoniści pytają, czy można w tym przypadku mówić jeszcze o prawdziwej i właściwej synodalności. Ich zdaniem jeszcze większe wątpliwości w tym względzie pojawiają się przy analizie norm poświęconych Radzie Hierarchów ${ }^{24}$. Bowiem zgodnie z kan. 167 §2 KKKW, wszelkie ustawy i normy wydane przez Radę Hierarchów nie mogą być ważnie promulgowane przed ich przyjęciem przez Stolicę Apostolską. Co więcej, także status Rady Hierarchów, będący podstawą jej działania, musi być uprzednio zatwierdzony przez Stolicę Apostolską (kan. $171 \mathrm{KKKW}$ ).

\section{Pozostałe Kościoły sui iuris}

W końcu ostatnie w hierarchii są Kościoły, o których w KKKW napisano Pozostate Kościoły sui iuris, czyli te, które nie są ani patriarchalne, ani arcybiskupie większe, ani metropolitalne. Są to zazwyczaj niewielkie okręgi terytorialne, ze zmieniającą się liczbą wiernych, dla których ustanawia się eparchie bądź egzarchaty, na czele których stoi hierarcha (biskup lub egzarcha), mianowany bezpośrednio przez Biskupa Rzymskiego. W większości zostały one historycznie uformowane poprzez odłączenie się niewielkich wspólnot od prawosławia. Kościoły te mają bardzo mały stopień autonomii w tym sensie, że są zależne bezpośrednio od Stolicy Apostolskiej, ich prawo (zarówno powszechne, jak i partykularne) jest wydawane przez Biskupa Rzymskiego, a hierarchowie, którzy im przewodzą, wykonują swoją władzę jako delegaci Biskupa Rzymskiego ${ }^{25}$. W ten sposób nietrudno wskazać

${ }^{24}$ Por. G. Mori, D. Salachas, Ordinamenti giuridici..., dz. cyt., s. 86-87. Obok Rady Hierarchów, Metropolita wspierany jest także przez zgromadzenie metropolitalne, ma ono jednak tylko głos doradczy w sprawach większej wagi, szczególnie jeśli chodzi o środki apostolstwa i dyscyplinę kościelną. Takie zgromadzenie winno być zwoływane przynajmniej raz na pięć lat (kan. $172 \mathrm{KKKW})$.

${ }^{25}$ Por. G. Mori, D. Salachas, Ordinamenti giuridici..., dz. cyt., s. 87-88; D. SalaCHAS, Commento al can. 174-176, w: P.V. Pinto (red.), Commento..., dz. cyt., s. 161- 
ich ścisły związek z Biskupem Rzymskim i ewidentną zależność od niego; przez tą ścisłą zależność Kościoły te są przez niektórych autorów nazywane romani iuris lub forme minori Kościołów sui iuris ${ }^{26}$. Można zatem powiedzieć, ̇̇e ich autonomia jest bardziej niż względna $i$ że jest porównywalna $z$ autonomia Kościołów partykularnych (diecezjileparchii), w ten sam sposób, jak to jest przewidziane w Kościele tacińskim ${ }^{27}$.

\section{Wewnętrzny podział administracyjny katolickich Kościołów wschodnich}

Specyfiką ustroju hierarchicznego Kościołów wschodnich jest również ich wewnętrzny podział administracyjny. Wedle prawa łacińskiego Kościoły partykularne, w których istnieje i odzwierciedla się Kościół powszechny, to przede wszystkim diecezje. W prawie wschodnim odpowiednikiem diecezji jest eparchia, analizując jednak normy prawne dotyczące ustroju katolickich Kościołów wschodnich, należy powiedzieć także o egzarchatach, a także o prowincjach istniejących w strukturze Kościołów patriarchalnych i arcybiskupich większych.

Prowincja to terytorium złożone z kilku eparchii, na czele którego stoi Metropolita Kościoła patriarchalnego lub arcybiskupiego większego. W ten sposób należy zauważyć przede wszystkim, że w katolickich Kościołach wschodnich istnieją dwa rodzaje Metropolitów: po pierwsze Metropolici Kościoła patriarchalnego lub arcybiskupiego większego, po drugie Metropolici Kościoła metropolitalnego sui iuris, o których była mowa powyżej. Różnica pomiędzy nimi polega na tym, że pierwszy z nich podlega bezpośrednio władzy Patriarchy lub Arcybiskupa większego, drugi z kolei jest głową Kościoła sui iuris, zależnego od Biskupa Rzymskiego.

162; M. Brogi, Le Chiese sui iuris nel Codex Canonum Ecclesiarum Orientalium, w: K. Bharanikulangara (red.), Il Diritto Canonico Orientale..., dz. cyt., s. 64.

${ }^{26}$ Por. D. SAlachas, Ecclesia universa et Ecclesia sui iuris nel Codice latino e nel Codice dei Canoni delle Chiese Orientali, Apollinaris 65(1992), s. 72; I. MonczAK, Appointments of Bishops in the Self-governing Eastern Catholic Churches, w: Congregazione per le Chiese Orientali, Ius Ecclesiarum Vehiculum Caritatis..., dz. cyt., s. 858.

${ }^{27}$ Por. G. Grigoriță, Il concetto..., dz. cyt., s. 78-79. 
Jak wynika z powyższego, prowincje mogą być tworzone jedynie w ramach Kościołów patriarchalnych i arcybiskupich większych; prawo nie przewiduje natomiast takich jednostek ani w zakresie Kościołów metropolitalnych, ani tym bardziej pozostałych Kościołów sui iuris (w tym ostatnim przypadku jest to logiczne o tyle, że prowincja jest terytorium złożonym z kilku eparchii, zaś owe pozostałe Kościoły sui iuris są same w sobie strukturalnie tworzone jako eparchie lub nawet egzarchaty). Natomiast w Kościołach patriarchalnych lub arcybiskupich większych, prowincje mogą być tworzone zarówno w ich granicach, jak i poza ich granicami. W pierwszym przypadku ich erygowanie, określanie nowych granic, łączenie, dzielenie, znoszenie należy do Patriarchy za zgodą Synodu Biskupów i po konsultacji ze Stolicą Apostolską (kan. 85 §1 KKKW), w drugim - jedynie do Biskupa Rzymskiego ${ }^{28}$.

Godność Metropolity jest zawsze związana z określoną stolicą eparchialną i w tejże eparchii Metropolita ma te same prawa i obowiązki co biskup eparchialny w swojej (kan. 134 KKKW). Natomiast w tym, co dotyczy uprawnień Metropolity w prowincji, którą zarządza, trzeba zwrócić uwagę na istotną różnicę pomiędzy Metropolitą ustanowionym w granicach terytorium Kościoła patriarchalnego lub arcybiskupiego większego a Metropolitą zarządzającym prowincją poza ich granicami. Otóż ich uprawnienia, wymienione w kan. $133 \S 1$ KKKW, odróżnia jedna kwestia: drugi z nich nie ma prawa wyświęcać i intronizować Biskupów prowincji, jako że prawo to, zgodnie z kan. $86 \S 2$ KKKW należy wyłącznie do Patriarchy lub Arcybiskupa większego.

Eparchia w katolickich Kościołach wschodnich odpowiada diecezji w Kościele rzymskokatolickim. Jest zatem zdefiniowana jako część ludu Bożego, która powierzona jest pasterskiej pieczy Biskupa ze współpracujacym z nim prezbiterium, tak by trwając przy nim jako swoim Pasterzu i zgromadzona przez niego w Duchu Świętym przez Ewangelię i Eucharystię, tworzyła Kościót partykularny, w którym prawdziwie obecny jest i działa jeden, święty, katolicki i apostolski Kościót Chrystusa (kan. $177 \S 1$ KKKW). Biskup rządzi zatem diecezją

${ }^{28}$ Por. D. Salachas, Commento al can. 138, w: P.V. Pinto (red.), Commento..., dz. cyt., s. 133. 
jako legat $i$ wikariusz Chrystusa (kan. 178 KKKW), a jego władza jest wykonywana osobiście, nie pochodzi więc z delegacji papieskiej. Oznacza to, że mówi się tu o władzy własnej, czyli sprawowanej w imieniu tego, kto ją wykonuje, a nie w imieniu żadnej innej władzy. Jest także zwyczajna, jako udzielona przez prawo ze względu na urząd biskupi i bezpośrednia, tzn. wykonywana bezpośrednio w stosunku do wiernych, bez żadnego pośrednictwa ${ }^{29}$.

Erygowanie, zmiana i zniesienie eparchii należy w granicach Kościoła patriarchalnego lub arcybiskupiego większego do zwierzchnika tegoż Kościoła, za zgodą Synodu Biskupów i po konsultacji ze Stolicą Apostolską. W pozostałych przypadkach prawo to należy do wyłącznej kompetencji Stolicy Apostolskiej (kan. 177 §2 KKKW). Podobnego rozróżnienia - przyjmując za kryterium granice Kościoła patriarchalnego lub arcybiskupiego większego - dokonuje prawodawca w kwestii ustanowienia eparchy: poprzez wybór lub poprzez nominację ze strony Biskupa Rzymskiego, o czym będzie mowa poniżej.

Jeśli wymagają tego pasterskie potrzeby eparchii, można ustanowić także biskupów pomocniczych, a w poważniejszych okolicznościach biskupa koadiutora z prawem sukcesji. Ponadto, w zarządzaniu eparchią, wspiera biskupa eparchialnego zgromadzenie eparchialne (kan. 235-242 KKKW), będące organem konsultacyjnym, zwoływanym i przewodniczonym przez biskupa (jest to odpowiednik synodu diecezjalnego w prawie Kościoła łacińskiego), a także rada kapłańska, kolegium konsultorów eparchialnych i rada duszpasterska (kan. 264$275 \mathrm{KKKW})$. W codziennym zarządzaniu eparchią wspiera biskupa także kuria eparchialna (kan. 243-263 KKKW). Analiza powyższych norm pozwala stwierdzić, że owe wewnętrzne zasady funkcjonowania eparchii są analogiczne z tymi, które przewidziane zostały w KPK dla zarządu diecezją. Specyfika prawa wschodniego w tym zakresie wyraża się jedynie w stosowanym nazewnictwie, tzn. łaciński wikariusz generalny, czyli ten, który obdarzony władzą zwyczajną i zastępczą, wspiera biskupa w zarządzie całą eparchią, w KKKW nazywa się Protosyncelem (kan. $245 \mathrm{KKKW}$ ). Natomiast łaciński wikariusz biskupi,

${ }^{29}$ Por. G. Mori, D. Salachas, Ordinamenti giuridici..., dz. cyt., s. 89. 
czyli ten, który ma taką samą władzę jak wikariusz generalny, ale tylko w określonej części diecezji lub w oznaczonym zakresie spraw albo w odniesieniu do wiernych jakiegoś obrządku względnie do pewnej grupy osób, nazywa się w KKKW Syncelem (kan. 246 KKKW). Podobnie nie ma żadnych różnic w określeniu parafii, proboszczów i wikariuszy parafialnych; jedynie dziekan, który przewodniczy okręgowi złożonemu z kilku parafii, nazywa się w KKKW Protoprezbiterem (kan. $276 \S 1 \mathrm{KKKW}$ ).

Brak natomiast w strukturze katolickich Kościołów wschodnich pojęcia wikariatu i prefektury apostolskiej oraz prałatury i opactwa terytorialnego. Istnieje natomiast egzarchat, który został zdefiniowany w KKKW jako cząstka Ludu Bożego, która w związu ze szczególnymi okolicznościami nie została erygowana jako eparchia, określona terytorialnie lub $w$ inny sposób (kan. $311 \S 1 \mathrm{KKKW}$ ). Motyw braku erygowania eparchii został zatem określony bardzo ogólnie, jako specialia adiuncta. Owe specjalne okoliczności mogą być zatem bardzo różne: brak realnych możliwości, kontekst historyczny, geograficzny, polityczny, społeczny i religijny wspólnoty, brak możliwości ekonomicznych, użyteczność i konieczność dobra duchowego wiernych, ochrony własnego obrządku ${ }^{30}$.

Odróżnia się egzarchaty erygowane przez Stolicę Apostolską, Patriarchę i Arcybiskupa większego; takie, którymi egzarcha zarządza $\mathrm{w}$ imieniu tego, kto go mianował lub w imieniu własnym; ponadto egzarchaty erygowane $\mathrm{w}$ granicach lub poza granicami Kościoła patriarchalnego lub arcybiskupiego większego.

W zakresie erygowania, zmiany i zniesienia, prawo wschodnie odróżnia pomiędzy egzarchatami znajdującymi się w granicach terytorium Patriarchatu lub Arcybiskupstwa większego oraz wszystkimi innymi egzarchatami. W pierwszym przypadku kompetencja $\mathrm{W}$ tym zakresie należy odpowiednio do Patriarchy lub Arcybiskupa większego, za zgodą Synodu Biskupów i po konsultacji ze Stolicą Apostolską. Natomiast wszystkie inne egzarchaty - poprzez które należy rozumieć

${ }^{30}$ Por. L. Sabbarese, Commento al can. 311, w: P.V. Pinto (red.), Commento..., dz. cyt., s. 277. 
te znajdujące się poza terytorium Kościoła patriarchalnego lub arcybiskupiego większego, jak również egzarchaty Kościołów metropolitalnych i wszystkich innych Kościołów sui iuris ${ }^{31}$ - mogą być erygowane, znoszone i zmieniane wyłącznie przez Stolicę Apostolską (kan. 311 §2 KKKW). Podobne normy dotyczą nominacji egzarchy: w granicach terytorium Kościoła patriarchalnego lub arcybiskupiego większego jest on mianowany przez Patriarchę lub Arcybiskupa większego za zgodą Synodu Stałego, zaś do jego odwołania potrzebna jest zgoda Synodu Biskupów. Prawodawca zastrzega jednak, że jeśli chodzi o egzarchę, który ma być wyświęcony na biskupa, wówczas należy zachować kanony dotyczące wyboru biskupów. Natomiast we wszystkich innych przypadkach, tzn. gdy chodzi o nominację egzarchy poza terytorium Kościoła patriarchalnego lub arcybiskupiego większego lub jakiegokolwiek innego egzarchy, nominacja należy wyłącznie do Stolicy Apostolskiej (kan. 314 KKKW).

O tym, czy egzarcha będzie zarządzał egzarchatem w imieniu tego, kto go mianował czy w imieniu własnym, powinno być postanowione w dekrecie erekcyjnym lub zmieniającym egzarchatu (kan. 312 KKKW). W pierwszym przypadku, egzarcha mianowany przez Stolicę Apostolską, Patriarchę lub Arcybiskupa większego, w ich imieniu - odpowiednio - zarządza egzarchatem, a jego władza jest zwyczajna, jako związana z urzędem, ale zastępcza. Jeśli natomiast zarządza egzarchatem we własnym imieniu, czyni to na mocy władzy zwyczajnej i własnej ${ }^{32}$.

W odniesieniu do praw egzarchów i egzarchatów prawodawca stanowi, że należy aplikować normy dotyczące biskupów eparchialnych i eparchii. W ten sposób trzeba zachować wszystko, co dotyczy praw i obowiązków biskupa eparchialnego, następnie sede plena, vacante i impedita, organów konsultacyjnych i uczestniczących w zarządzaniu eparchią, parafii i proboszczów. Ta zasada ogólna jest jednak ograni-

\footnotetext{
${ }^{31}$ Por. tamże.

${ }^{32}$ Por. L. Sabbarese, Commento al can. 312, w: P.V. Pinto (red.), Commento..., dz. cyt., s. $277-278$.
} 
czona przez dwie sytuacje: jeśli co innego zostało wyraźnie postanowione w prawie lub z natury rzeczy inaczej wynika (kan. $313 \mathrm{KKKW}$ ).

\section{Wybór biskupów wschodnich}

O specyfice ustroju hierarchicznego katolickich Kościołów wschodnich stanowi bez wątpienia sposób wyboru biskupów, dlatego wypada poświęcić temu zagadnieniu nieco więcej uwagi. Zgodnie z kan. 376 KPK biskupów w sposób nieskrępowany minuje papież albo zatwierdza wybranych zgodnie z prawem. Ostateczna decyzja dotycząca nominacji biskupa należy zawsze wyłącznie do Biskupa Rzymskiego ${ }^{33}$. Natomiast wedle regulacji wschodniej biskupi desygnowani są przez kanoniczny wybór lub przez nominację ze strony Biskupa Rzymskiego, a kryterium tego rozróżnienia stanowią granice terytorium Kościoła patriarchalnego lub arcybiskupiego większego (kan. $181 \mathrm{KKKW}$ ).

W każdym przypadku - a zatem niezależnie od sposobu desygnowania biskupa, prawodawca stawia konkretne wymagania, jakie musi spełniać kandydat, aby mógł być uznany za zdatnego do biskupstwa. W kan. 180 KKKW przewiduje bowiem, że od kandydata wymaga się niezachwianej wiary, dobrych obyczajów, pobożności, gorliwości o dusze i szczególnej roztropności; dobrej sławy; wolności od węzła małżeńskiego; przynajmniej trzydziestu pięciu lat życia; przynajmniej pięciu lat prezbiteratu oraz doktoratu lub licencjatu albo przynajmniej biegłości w jakiejś świętej dyscyplinie. Warto dodać, że prawo partykularne poszczególnych Kościołów sui iuris ustanawia niekiedy bardziej szczegółowe normy w tej materii. Przykładem takowych mogą być regulacje obowiązujące w Ukraińskim Kościele Greckokatolickim, w którym nie wprowadza się wprawdzie żadnych nowych wymagań dla kandydatów, oddaje się jednak do dyspozycji członków Synodu Biskupów ankietę zawierającą szczegółowe pytania odnoszące się do poszczególnych właściwości, umiejętności czy zdolności kandydata ${ }^{34}$.

${ }^{33}$ Por. J. Krukowski, Komentarz do kan. 376, w: J. Krukowski (red.), Komentarz do Kodeksu Prawa Kanonicznego, Tom II. 1, Poznań 2005, s. 232-233.

${ }^{34}$ Por. P. W. Pотосzny, Biskup w Ukraińskim Kościele Greckokatolickim (sposób powołania na urzą), http://www.cerkiew.net/page.php?20 (data 
W pierwszym przypadku, a zatem wewnątrz granic terytorium

dostępu: 7 września 2012 r.). Wśród pytań zawartych w ankiecie znajdują się następujące: 1.Kontakty i znajomość między kandydatem i proponującym (jak długo znają się, jak długo przebywali w swoim towarzystwie); 2. Zdolność kandydata do przyjęcia sakry biskupiej (wygląd zewnętrzny, stan zdrowia, czy jest zdatny do pracy, stan cywilny (samotny, żonaty, rozwiedziony, wdowiec), czy w rodzinie kandydata kiedykolwiek były przypadki dziedzicznej choroby fizycznej czy psychicznej); 3. Cechy charakteru kandydata (zdolności intelektualne (odpowiednia wiedza, stopień naukowy), temperament (czy jest zrównoważony, rozsądny, uparty, niezdecydowany, uległy, fanatyczny), czy ma poczucie odpowiedzialności i obowiązku); 4. Charakterystyka kandydata jako człowieka, chrześcijanina, księdza (cnoty chrześcijańskie umiarkowanie, rozsądek, sprawiedliwość, życie moralne, lojalność, wiara, nadzieja, miłość, posłuszeństwo, miłosierdzie, pokora, pobożność), cnoty kapłańskie (codziennie służy Boską Liturgią, odmawia Liturgię Godzin, posiada powagę do Najświętszej Bogurodzicy); 5. Zachowanie kandydata (teraźniejsze i w przeszłości, nawiązywanie kontaktów i przyjazny stosunek do wiernych i do władz cywilnych, czy opiekuje się i troszczy się o potrzebujących); kulturowo-naukowy poziom kandydata (orientacja i znajomość spraw współczesnego świata, znajomość języków, przede wszystkim języka ukraińskiego, następnie języka kraju, z którego pochodzi, a także innych, publikacje książkowe bądź artykuły których jest autorem); 7 Prawowierność (prawdziwość wyznawanej nauki: akceptacja nauki Kościoła Katolickiego, czy przyjmuje on tę naukę z przekonaniem, lojalnie i z wiernością, stosunek do nauczania Kościoła o kapłaństwie, jaki jest jego stosunek do wyświęcania kobiet, jaki ma stosunek do sakramentu małżeństwa); 8. Stosunek kandydata do prawa Kościoła (czy jest ono przez niego poważane, czy zgadza się z nim (prawo o kapłaństwie żonatych, o stosunku do celibatu i życia zakonnego), przyjęcie nauczania Soboru Watykańskiego II, przyjmowanie nauczania Papieża, czy jest lojalny i ma cnotę posłuszeństwa wobec Rzymskiego Archijereja, Stolicy Apostolskiej, Hierarchii i Synodu, jak zachowuje własną tradycję przepisów liturgicznych); 9. Zdolność prowadzenia ludu Bożego (czy posiada zdolności organizacyjne oraz wszelkie predyspozycje do tego, aby dobrze sprawować urząd pasterski, czy jest dobrym mówcą, czy przygotowuje się do głoszonych przez siebie homilii i czy rzetelnie wyjaśnia prawdy wiary, dbałość o dziedzictwo kulturowe, o cały majątek kościoła); 10. Własna opinia wypełniającego ankietę o kandydacie. 
Kościoła patriarchalnego lub arcybiskupiego większego, biskupi są desygnowani przez kanoniczny wybór dokonywany przez Synod Biskupów danego Kościoła. Przed jego zwołaniem każdy z członków Synodu Biskupów ma prawo proponować kandydatów zdatnych do biskupstwa, co wiąże się z przeprowadzeniem zgodnego z prawem partykularnym procesu informacyjnego. Polega on na zebraniu informacji i dokumentów niezbędnych dla potwierdzenia zdatności danego kandydata, które następnie biskupi powinni przekazać Patriarsze. Ten zaś, po ewentualnym dołączeniu własnych informacji, powinien przekazać je pozostałym członkom Synodu Biskupów. Jeżeli prawo partykularne zaaprobowane przez Biskupa Rzymskiego, nie stanowi czegoś innego, Synod Biskupów Kościoła patriarchalnego sprawdza nazwiska kandydatów i po przeprowadzeniu tajnego głosowania tworzy listę kandydatów, którą Patriarcha przesyła Stolicy Apostolskiej w celu otrzymania zatwierdzenia od Biskupa Rzymskiego (kan. $182 \mathrm{KKKW}$ ).

Biskupi wybierani są absolutną większością głosów $(50 \%+1)$, przy obecności 2/3 tych, którzy należą do Synodu Biskupów, a w konsekwencji powinni wziąć w nim udział. Prawo przewiduje, że po trzech bezskutecznych głosowaniach w czwartym głosowaniu głosuje się na dwóch kandydatów, którzy w trzecim głosowaniu otrzymali najwięcej głosów. Jeśli zaś w trzecim lub w czwartym głosowaniu liczba głosów jest równa, rozstrzyga się na korzyść tego, kto jest starszy święceniami prezbiteratu, a jeśli i tu jest równość, na korzyść tego, kto jest starszy wiekiem (kan. $183 \mathrm{KKKW}$ ).

Mimo sporządzonej uprzednio listy kandydatów, prawodawca nie ogranicza jednak możliwości wyboru jedynie spośród tych, których nazwiska się na niej znalazły. Przewidując jednak możliwość przeciwną, ustanawia dwie procedury działania po dokonanym kanonicznie wyborze. Wskazuje bowiem, w kan. 184 KKKW, że jeśli został wybrany kandydat $\mathrm{z}$ listy zatwierdzonej przez Papieża, wówczas o wyborze należy zawiadomić, z zachowaniem tajemnicy, elekta, zaś po przyjęciu przez niego wyboru - Stolicę Apostolską. Gdyby natomiast wybrano kandydata spoza listy, wówczas przed oznajmieniem elektowi wyboru Patriarcha powiadamia Stolicę Apostolską w celu otrzymania zgody 
Biskupa Rzymskiego, z zachowaniem tajemnicy przez wszystkich, którzy w jakikolwiek sposób dowiedzieli się o wyniku wyboru, także wobec elekta, aż do czasu nadejścia informacji o zatwierdzeniu.

Może się zdarzyć także sytuacja, w której z jakiegoś powodu Synod Biskupów nie może się zebrać. Wiadomo przecież, że Kościoły katolickie wschodnie istnieją w różnych warunkach społecznych i politycznych, które nie zawsze dają możliwości swobodnego działania. Dlatego na taką sytuację prawodawca, w kan. $186 \mathrm{KKKW}$, przewiduje szczególny sposób przeprowadzenia wyboru biskupów. Mianowicie wówczas Patriarcha, względnie Arcybiskup większy, po konsultacji ze Stolicą Apostolską, powinien zebrać głosy biskupów na piśmie, wyznaczając do tego, zgodnie z prawem partykularnym, dwóch biskupów jako skrutatorów. Ci, z zachowaniem tajemnicy, mają otworzyć pisma biskupów, policzyć głosy i sporządzić protokół z przeprowadzonego głosowania, który podpisują skrutatorzy i Patriarcha. Wówczas, jeśli ktoś otrzymał absolutną liczbę głosów, zostaje wybrany biskupem i należy postępować tak, jak przy zwyczajnych wyborach. W przeciwnym wypadku, sprawę należy przekazać Stolicy Apostolskiej.

Tak wygląda procedura wyboru biskupów w granicach terytoriów Kościoła patriarchalnego lub Arcybiskupiego większego. Natomiast w każdym innym przypadku, czyli jeśli ma być ustanowiony biskup poza terytorium tychże Kościołów, lub gdy chodzi o biskupów dla Kościołów metropolitalnych lub pozostałych Kościołów sui iuris, wówczas są oni mianowani przez Biskupa Rzymskiego. W stosunku do kandydatów na biskupów, którzy mają być ustanowieni poza terytorium Kościoła patriarchalnego lub arcybiskupiego większego, Synod Biskupów, wedle wyżej wskazanych kanonów o wyborach biskupów, wybiera przynajmniej trzech kandydatów, których następnie Patriarcha (Arcybiskup większy) przedstawia do nominacji Papieżowi (kan. $149 \mathrm{KKKW}$ ). Bardzo podobnie wygląda procedura przy nominacji biskupów w Kościołach metropolitalnych: wówczas Rada Hierarchów sporządza listę trzech przynajmniej kandydatów najbardziej odpowiednich i następnie w tajemnicy przekazuje ją Stolicy Apostolskiej (kan. 168 KKKW). 
W każdym przypadku elekt czy nominat, który został wybrany czy mianowany, musi w pierwszej kolejności, jeszcze przed święceniami, złożyć wyznanie wiary oraz przysięgę posłuszeństwa wobec Biskupa Rzymskiego, a w Kościołach Patriarchalnych i Arcybiskupich większych także wobec Patriarchy czy Arcybiskupa większego. Następnie w ciągu 3 miesięcy od chwili ogłoszenia (jeśli był wybrany) lub otrzymania pisma apostolskiego (jeśli był mianowany), powinien otrzymać święcenia biskupie, natomiast w ciągu 4 miesięcy objąć eparchię w kanoniczne posiadanie. Dokonuje się to poprzez intronizację, podczas której odczytuje się list apostolski lub patriarchalny o prowizji kanonicznej. Do tego czasu biskup-elekt nie może ingerować w zarząd eparchii (kan. 187-189 KKKW).

\section{Zakończenie}

Analiza norm dotyczących ustroju hierarchicznego katolickich Kościołów wschodnich pozwala bez wątpienia stwierdzić, że Kodeks Kanonów Kościołów Wschodnich pozostał wierny starożytnej tradycji wschodniej, jak również wskazaniom Soboru Watykańskiego II. Świadczą o tym nade wszystko kanony dotyczące Kościołów patriarchalnych, lecz nie tylko. Trzeba powiedzieć, że cały ustrój katolickich Kościołów wschodnich jest właściwy duchowi wschodniemu i odzwierciedlający go. Jednocześnie także nie ma wątpliwości, że każde z poruszanych wyżej zagadnień mogłoby zostać omówione znacznie szerzej, każdemu można byłoby poświęcić oddzielną pracę naukową. Celem powyższego studium było jednak nade wszystko wskazanie tego, co szczególne, wyjątkowe, specyficzne, tego, co w sposób najbardziej wyraźny odróżnia strukturalnie katolicyzm wschodni od Kościoła łacińskiego. A takich różnic jest rzeczywiście bardzo wiele.

\section{Specificity of the hierarchical system of the Eastern Catholic Churches}

A matter of the hierarchical system is one of the specific issues regulated in CCEO. Its specificity is expressed in the fact that four hierarchical types of Eastern Churches sui iuris are known in the east- 
ern legislature. The hierarchical type of Eastern Church depends on its importance given to it by the supreme ecclesiastic authority. Resulting in a major or minor rank of its autonomy. These are namely: the patriarchal Churches, Archbishop's Churches, Larger Metropolitan Churches and other sui iuris Churches. The subject of the article is analysis further Codex standards, as well as taking into the account the internal administrative division of Churches and the characteristic to the eastern law the designation way of eastern bishops. 